\title{
Zastosowanie ziemskich izotopów kosmogenicznych w datowaniu glin lodowcowych - potencjal, ograniczenia i perspektywy badawcze
}

\author{
Karol Tylmann ${ }^{1}$, Damian Moskalewicz ${ }^{2}$
}

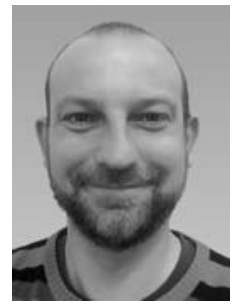

K. Tylmann

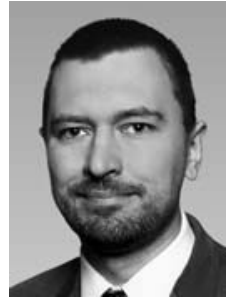

D. Moskalewicz

Application of in situ cosmogenic nuclides in dating glacial till - research potential, limitations and prospects. Prz. Geol., 68: 764-773; doi: 10.7306/2020.32

A b s tra c t. Determination of numerical age for glacial till is one of the most intriguing issues in glacial geology and geomorphology. Till layers are unequivocal evidence of ice sheets advances and retreats, and therefore they are very important for Quaternary palaeoclimatic reconstructions. Herein, we present a review dedicated to the methodology of glacial till dating with in situ cosmogenic nuclides. This relatively novel approach enables direct dating of deposition of till and its exposure after deglaciation. Getting reliable numerical age (in years) of till opens a new prospect for reconstructions of past glaciations and palaeogeographic studies. Despite some limitations of applying in situ cosmogenic exposure and burial dating, we argue that this technique may be successfully employed in studies of glacial deposits in Poland.

Keywords: in situ cosmogenic nuclides, glacial till, burial dating

Wiek gliny lodowcowej jest jednym z najbardziej istotnych zagadnień geologii czwartorzędu. Poziomy glin lodowcowych, które powszechnie występują w profilach osadów plejstocenu, są bezsprzecznym zapisem obecności lądolodów. Mają więc ważną wymowę paleoklimatyczną, a określanie ich wieku umożliwia tworzenie chronologii zdarzeń glacjalnych i związanych z nimi transgresji oraz recesji lądolodów. W związku z tym przyporządkowanie glin lodowcowych do poszczególnych zlodowaceń i określenie wieku bezwzględnego zdarzeń glacjalnych jest niezwykle ważne dla poprawności schematów stratygraficznych, jak również rekonstrukcji paleogeograficznych. Niestety, datowanie wieku glin lodowcowych nastręcza wielu trudności. Materia organiczna i skamieniałości zawarte w glinach są redeponowane, więc nie nadają się do precyzyjnego określenia wieku osadu metodą radiowęglową. Osady te nie były też dostatecznie eksponowane na światło słoneczne podczas transportu i depozycji, aby możliwe było efektywne zastosowanie metod luminescencyjnych. W przeszłości próbowano wykorzystać między innymi metodę termoluminescencyjną (TL) do bezpośredniego datowania wieku glin (np. Lindner i in., 1989; Olszak i in., 2008), jednak okazała się ona niepoprawna z metodycznego punktu widzenia i obecnie jest uważana za niewiarygodną. Dlatego też stratygrafia glin lodowcowych oraz wynikająca $\mathrm{z}$ niej chronologia zlodowaceń była dotychczas ustalana na podstawie wyników analizy składu petrograficznego glin (ryc. 1A) oraz datowania osadów znajdujących się pod spagiem i nad stropem glin (ryc. 1B).

Badania litopetrograficzne umożliwiają lokalną korelację warstw glin i powiązanie ich z poszczególnymi zlodowaceniami (Czerwonka i in., 1997; Gałązka i in., 1999; Lisicki, 2003; Czerwonka, 2004; Woźniak, 2004; Zabielski, 2004). Za pomocą datowania radiowęglowego szczątków i osadów organicznych występujących pod i nad gliną określa się jej minimalny i maksymalny wiek (np. Zaretskaya i in., 2020), jednak metodę tę można stosować do określania wieku jedynie tych osadów, które powstały w ciągu ostat-
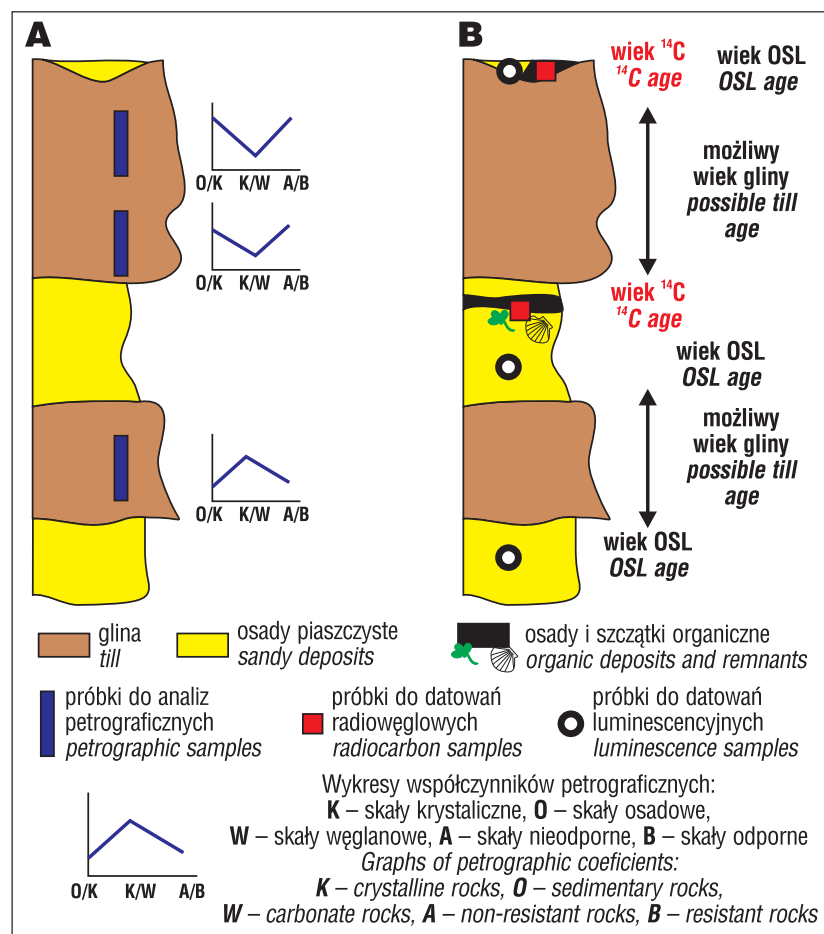

Ryc. 1. Tradycyjne metody określania wieku gliny lodowcowej: A - ustalanie względnej pozycji stratygraficznej na podstawie badań petrograficznych; B - określanie wieku gliny z wykorzystaniem datowania radiowęglowego materii organicznej lub datowania OSL osadów mineralnych występujących pod spagiem gliny i nad jej stropem

Fig. 1. Traditional methods of till dating: $\mathbf{A}$ - determination of the relative stratigraphic order based on petrographic studies; $\mathbf{B}$ - estimation of till age with radiocarbon dating of organic matter or OSL dating of mineral deposits occurring below and above the till

nich 50 tys. lat (Hajdas i in., 2008). Podobnie, na podstawie wyników badań osadów mineralnych znajdujących się pod

\footnotetext{
${ }^{1}$ Zakład Geofizyki, Wydział Oceanografii i Geografii, Uniwersytet Gdański, al. Marszałka Piłsudskiego 46, 81-378 Gdynia; k.tylmann@ug.edu.pl

${ }^{2}$ Zakład Geomorfologii i Geologii Czwartorzędu, Wydział Oceanografii i Geografii, Uniwersytet Gdański, ul. Bażyńskiego 4, 80-309 Gdańsk; damian.moskalewicz@ug.edu.pl
} 
i nad gliną lodowcową - reprezentujących zazwyczaj środowiska fluwialne, fluwioglacjalne oraz eoliczne - możliwe jest określenie wieku minimalnego i maksymalnego gliny z zastosowaniem metod luminescencyjnych, z których najpowszechniej jest stosowana metoda optycznie stymulowanej luminescencji - OSL (np. Przegiętka i in., 2008; Wysota $\mathrm{i}$ in., 2009; Weckwerth i in., 2011; Hardt i in., 2016).

Problem określania wieku glin lodowcowych jest wciąż istotną kwestią, która nierzadko budzi duże kontrowersje i ożywione dyskusje w środowisku geologów czwartorzędu i geomorfologów. Pod wątpliwość poddaje się zarówno zasadność stosowania określonych metod w datowaniu glin (np. luminescencji), jak również interpretacje chronologii zlodowaceń uzyskane w rezultacie datowania osadów towarzyszących glinom i uznanych za odpowiednie do datowania luminescencyjnego (np. Bluszcz, 2000; Alexanderson, Murray, 2009). Jest to spowodowane dużą złożonością procesów sedymentacji, erozji i deformacji, działających w środowisku glacjalnym, które zapisują się w profilach osadów plejstoceńskich (Fuchs, Owen, 2008).

W ciagu ostatnich 20-30 lat nastapił duży postęp w badaniach wykorzystujących do datowania ziemskie izotopy kosmogeniczne (TCN - Terrestrial Cosmogenic Nuclides). Mają one zastosowanie w badaniach osadów różnych środowisk sedymentacji, w tym środowiska glacjalnego. Dotychczas wykorzystywano je $-\mathrm{np}$. izotopy ${ }^{10} \mathrm{Be},{ }^{26} \mathrm{Al}$ oraz ${ }^{36} \mathrm{Cl}$ - głównie do określania wieku ekspozycji na promieniowanie kosmiczne głazów narzutowych oraz przekształconych glacjalnie wychodni skalnych (np. Briner i in., 2014; Potter i in., 2019; Tylmann i in., 2019). Coraz większą popularność zyskuje też zastosowanie wymienionych izotopów do określania wieku osadów pogrzebanych (Granger, Muzikar, 2001), w tym glin lodowcowych (Balco i in., 2005a, b, c; Wüthrich i in., 2017). Celem niniejszego przeglądowego artykułu jest prezentacja możliwości bezpośredniego datowania glin lodowcowych na podstawie analizy koncentracji ziemskich izotopów kosmogenicznych oraz ocena potencjału i ograniczeń tej metody.

\section{ZIEMSKIE IZOTOPY KOSMOGENICZNE}

Mechanizm powstawania ziemskich izotopów kosmogenicznych jest szeroko opisywany w literaturze anglojęzycznej (np. Gosse, Philips, 2001; Dunai, 2010; Darvill, 2013), jak również w niektórych publikacjach polskojęzycznych (np. Sobczyk, 2016), dlatego w tym artykule przytoczono jedynie najważniejsze informacje dotyczące ich powstawania oraz możliwości wykorzystania w badaniach geologicznych i geomorfologicznych.

Promieniowanie kosmiczne składa się z cząstek wysokoenergetycznych, tj. protonów, elektronów, cząstek $\alpha$ i ciężkich jąder (Gosse, Philips, 2001). Jego źródłem są przede wszystkim wybuchy supernowych, a w bezpośrednim otoczeniu Ziemi również aktywność Słońca. Promieniowanie docierające do naszej planety jest znacząco redukowane przez ziemskie pole magnetyczne, które zakrzywia trajektorie przepływu cząstek i uniemożliwia penetrację atmosfery ziemskiej przez ich większą część. Jedynie cząstki o odpowiednio dużej energii pokonują barierę ziemskiego pola magnetycznego i docierają do atmosfery (Darvill, 2013). Wskutek odziaływań zachodzących pomiędzy tymi cząstkami a atomami pierwiastków obecnych w atmosferze dochodzi do wielu reakcji jądrowych, w wyniku których powstają izotopy kosmogeniczne nazywane atmosferycznymi lub też meteorycznymi (ryc. 2). Oprócz izotopów atmosferycznych (np. $\left.{ }^{10} \mathrm{Be},{ }^{14} \mathrm{C},{ }^{21} \mathrm{Ne}\right)$ efektem tych

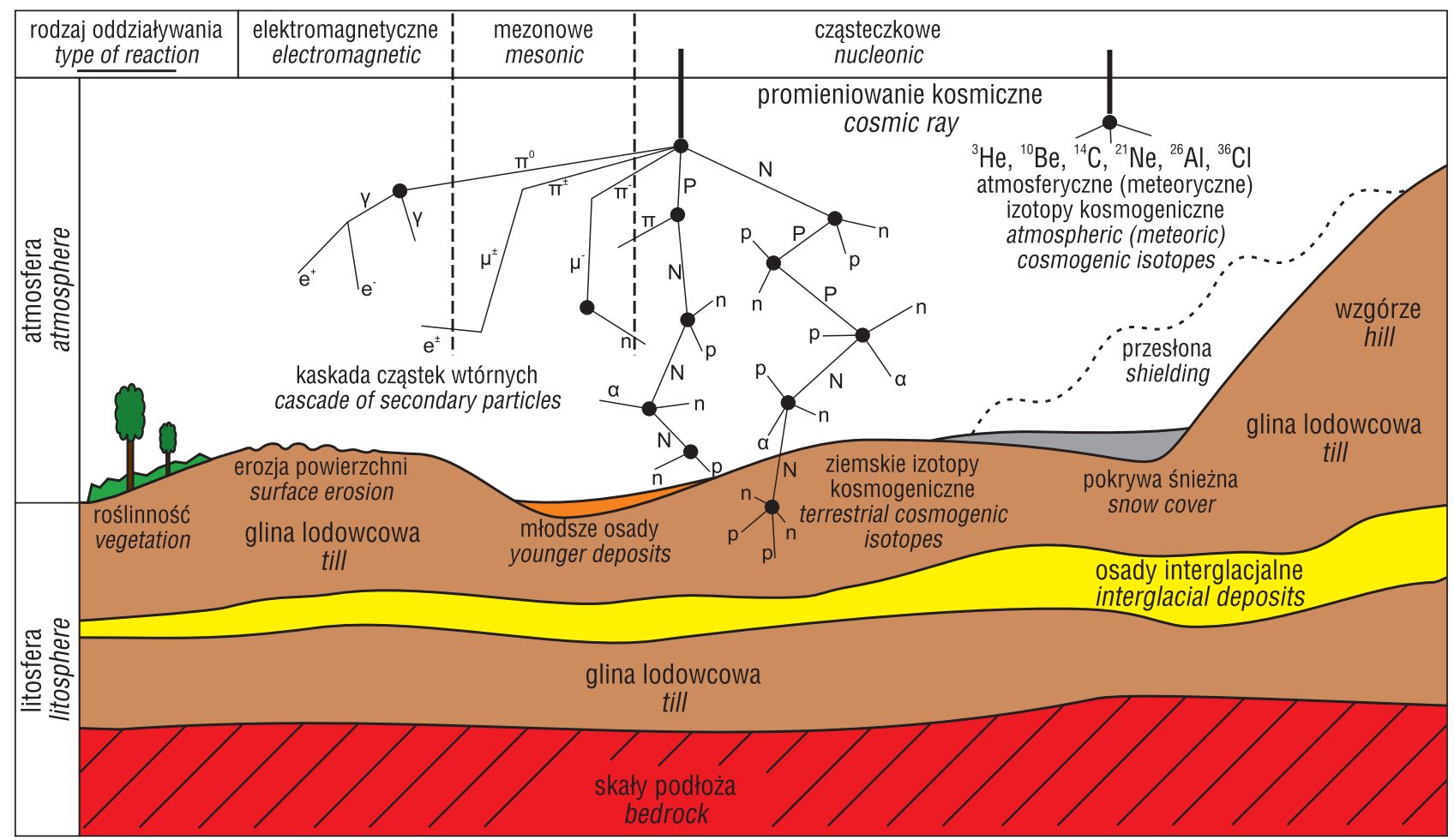

Ryc. 2. Schemat powstawania izotopów kosmogenicznych w atmosferze i powierzchniowych warstwach litosfery wraz z lokalnymi czynnikami wpływającymi na tempo ich produkcji: $\mathrm{e}^{+}$- pozytron, $\mathrm{e}^{-}-$elektron, $\gamma$ - foton (gamma), $\alpha$ - cząstka alfa, $\mathrm{N}, \mathrm{n}-\mathrm{neutron}$, $\mathrm{P}, \mathrm{p}$ - proton, $\pi$ - pion, $\mu$ - mion (opracowano na podstawie Darvill, 2013)

Fig. 2. Formation of cosmogenic nuclides in atmosphere and surficial layers of lithosphere, and local factors influencing nuclides production rate: $\mathrm{e}^{+}-$positron, $\mathrm{e}^{-}-$electron, $\gamma$-photon (gamma), $\alpha$-alpha particle, $\mathrm{N}, \mathrm{n}-$ neutron, $\mathrm{P}, \mathrm{p}-$ proton, $\pi-$ pion, $\mu-$ muon (figure based on Darvill, 2013) 
reakcji są również liczne nowe cząstki, np. neutrony, protony, elektrony, pozytrony, miony, piony, cząstki $\alpha$ i inne, które tworzą tzw. kaskadę wtórnego promieniowania kosmicznego (Gosse, Philips, 2001). Po dotarciu do powierzchni Ziemi promieniowanie to wywołuje reakcje jądrowe w minerałach występujących w powierzchniowej warstwie litosfery. Efektem tych reakcji jest formowanie w sieciach krystalicznych ziemskich minerałów izotopów kosmogenicznych, czyli tzw. izotopów in situ (ryc. 2). Większość z nich to izotopy nietrwałe (radionuklidy), zanikające zgodnie z określonym czasem połowicznego rozpa$\mathrm{du}\left(\mathrm{np} .{ }^{10} \mathrm{Be},{ }^{26} \mathrm{Al},{ }^{14} \mathrm{C},{ }^{36} \mathrm{Cl}\right)$, choć zdarzają się również izotopy stabilne (np. ${ }^{21} \mathrm{Ne} \mathrm{czy}{ }^{3} \mathrm{He}$ ).

Tempo produkcji izotopów kosmogenicznych in situ jest uzależnione od kilku czynników, z których najważniejsze to: szerokość geograficzna, wysokość nad poziomem morza i stopień przesłonięcia horyzontu $\mathrm{w}$ miejscu poboru próbek (wyrażony pomiarami azymutu oraz wysokości kątowej przeszkód topograficznych przesłaniających linię horyzontu; ma on istotne znaczenie w obszarach górskich, na nizinach jest zazwyczaj pomijany), jak również nachylenie analizowanej powierzchni oraz miąższość i cechy fizyczne osadów, skał, śniegu bądź roślinności, które ją pokrywają (Darvill, 2013). Tempo to wyraża się w atomach powstających w jednym gramie danego minerału w ciagu jednego roku i bywa ono również nazywane dawką roczną. Dawka ta jest wyznaczana dla poszczególnych izotopów na podstawie: 1) kalibracji geologicznej, czyli pomiarów koncentracji danego izotopu kosmogenicznego w skałach o znanym czasie ekspozycji, precyzyjnie określonym niezależnymi metodami datowania, np. metodą radiowęglową (m.in. Schimmelpfennig i in., 2012; Putnam i in., 2019); 2) pomiarów eksperymentalnych, np. w materiałach wystawionych przez kilka lat na promieniowanie kosmiczne na dużych wysokościach (np. Nishiizumi i in., 1996) oraz 3) numerycznego modelowania interakcji promieniowania kosmicznego docierającego do powierzchni Ziemi z minerałami (Masarik, Reedy, 1995). Badania tego typu doprowadziły do opracowania globalnych i lokalnych dawek rocznych poszczególnych izotopów, znormalizowanych do poziomu morza oraz wysokich szerokości geograficznych (>60; SLHL - Sea Level High Latitude; Dunai, 2010). Na przykład tempo produkcji izotopów kosmogenicznych ${ }^{26} \mathrm{Al},{ }^{10} \mathrm{Be}$ oraz ${ }^{14} \mathrm{C}$ w kwarcu, obliczone na podstawie globalnego zestawu danych, wynosi odpowiednio 28,54; 3,92 oraz 12,76 atomów $\cdot \mathrm{g}^{-1} \cdot \operatorname{rok}^{-1}$ (Borchers i in., 2016). Zastosowanie tzw. skalowania umożliwia określenie dawki rocznej danego izotopu w dowolnej szerokości i długości geograficznej oraz wysokości nad poziomem morza (Lal, 1991). Istotny wpływ na lokalne tempo produkcji izotopów kosmogenicznych ma także przesłonięcie horyzontu czy też nachylenie analizowanej powierzchni (ryc. 2).

Pierwsze badania geologiczne z wykorzystaniem izotopów kosmogenicznych prowadzono w drugiej połowie XX w., gdy po udanych testach na skałach pochodzenia księżycowego rozpoczęto badania na skałach ziemskich (m.in. Davis, Schaffer, 1955; Srinivasan, 1976; Klein i in., 1986). Wraz z pojawieniem się nowych możliwości pomiarów bardzo niewielkich koncentracji izotopów w próbkach za pomocą atomowej spektrometrii mas (Christl i in., 2014) izotopy kosmogeniczne znalazły szerokie zastosowanie w naukach o Ziemi, obejmujące m.in.: rekonstrukcje chronologii zdarzeń glacjalnych, datowanie erupcji wulkanicz- nych i procesów tektonicznych, chronologię formowania tarasów rzecznych, datowanie ruchów masowych, określanie tempa denudacji i rozwoju procesów glebowych, a także datowanie ekspozycji i pogrzebania osadów w różnych środowiskach sedymentacyjnych (m.in. Ivy-Ochs $\mathrm{i}$ in., 1998; Liu i in., 2013; Ivy-Ochs, Briner, 2014; Benedetti, Woerd, 2014; Dixon, Riebe, 2014; Ruszkiczay-Rüdiger i in., 2016). Niestabilne ziemskie izotopy kosmogeniczne moga być także $\mathrm{z}$ powodzeniem wykorzystywane $\mathrm{w}$ datowaniu osadów o genezie glacjalnej (Balco i in., 2005a, b, c; Balco, Rovey, 2008; Hein i in., 2009; Darvill i in., 2015).

\section{IZOTOPY KOSMOGENICZNE JAKO NARZĘDZIE DO DATOWANIA GLIN}

Zjawisko powstawania niestabilnych izotopów kosmogenicznych in situ w warstwach eksponowanych na działanie wtórnego promieniowania kosmicznego oraz zahamowanie tego procesu i promieniotwórczy rozpad tych izotopów w warstwach odciętych od wpływu promieniowania można wykorzystać do określenia czasu pogrzebania i ekspozycji osadów (Fabel, Harbor, 1999; Granger, Muzikar, 2001; Dehnert, Schlüchter, 2008). Możliwość ta odnosi się także do warstw bazalnych glin lodowcowych, które nie nadają się do bezpośredniego datowania z zastosowaniem innych metod.

Glina bazalna powstaje w specyficznych warunkach depozycji materiału morenowego w strefie kontaktu stopy lądolodu z podłożem (Evans i in., 2006). W rezultacie procesów subglacjalnych, oddziałujących pomiędzy lądolodem a jego podłożem, takich jak. odkładanie, wytapianie czy deformacja, materiał morenowy transportowany w lodzie oraz materiał inkorporowany przez lądolód z podłoża są deponowane najczęściej w formie diamiktonu tworzącego warstwę gliny lodowcowej. Osad ten jest więc odcięty od wpływu promieniowania kosmicznego podczas transportu i depozycji pod lądolodem, co umożliwia wykorzystanie niestabilnych izotopów kosmogenicznych (np. takich, jak powstające w kwarcu ${ }^{10} \mathrm{Be},{ }^{26} \mathrm{Al} \mathrm{czy}{ }^{14} \mathrm{C}$ ) i zmian ich zawartości w profilu pionowym do określenia czasu ekspozycji lub pogrzebania warstw glin.

\section{Czas ekspozycji glin na promieniowanie}

Gliny, które występują na powierzchni terenu i są zapisem ostatniego epizodu glacjalnego na danym obszarze, można datować za pomocą izotopów kosmogenicznych, określając czas ich ekspozycji na promieniowanie po deglacjacji. Mechanizm tego typu datowania polega na analizie zawartości badanego izotopu w profilu gliny oraz dopasowaniu najbardziej odpowiedniej krzywej zmian jego zawartości wraz z głębokością, której przebieg zależy między innymi od czasu ekspozycji warstwy osadu na działanie wtórnego promieniowania kosmicznego (m.in. Hidy i in., 2010; Dortz i in., 2012; Wüthrich i in., 2017).

Roczna produkcja danego izotopu kosmogenicznego na określonej głębokości w profilu osadów jest zależna od tempa jego produkcji na powierzchni Ziemi, głębokości, na której znajduje się badana próbka, gęstości pokrywających ją osadów oraz tłumienia wyrażonego jako współczynnik osłabienia strumienia promieniowania kosmicznego wraz z głębokością, zgodnie z następującą formułą (Gosse, Philips, 2001): 


$$
P_{z}=P_{0} e^{-z} \frac{\rho}{\Lambda}
$$

gdzie:

$P_{z}$ - roczna dawka izotopu na głębokości $z$ [atomy $\cdot \mathrm{g}^{-1}$. rok $\left.^{-1}\right]$;

$P_{0}$ - roczna dawka izotopu na powierzchni Ziemi [atomy

$\mathrm{g}^{-1} \cdot$ rok $^{-1}$;

$z$-głębokość [cm];

$\rho$ - gęstość osadu $\left[\mathrm{g} \cdot \mathrm{cm}^{-3}\right]$;

$\Lambda$ - współczynnik osłabienia strumienia promieniowania wraz z głębokością $\left[\mathrm{g} \cdot \mathrm{cm}^{-2}\right]$.

Roczna dawka danego izotopu zmniejsza się więc wykładniczo wraz ze wzrostem głębokości w badanym profilu osadów. W konsekwencji również zawartość tego izotopu w osadzie spada wykładniczo wraz ze wzrostem głębokości, a całkowitą koncentrację na danej głębokości można obliczyć, korzystając ze wzoru (Gosse, Philips, 2001):

$$
C_{(t, z)}=\frac{P_{z}}{\lambda+\frac{\rho \varepsilon}{\Lambda}}\left(1-e^{-\left(\lambda+\frac{\rho \varepsilon}{\Lambda}\right) t}\right)+C_{i n h} e^{-\lambda t}
$$

gdzie:

$C_{(t, z)}$ - koncentracja izotopu po czasie $t$ na głębokości $z$ [atomy $\cdot \mathrm{g}^{-1}$;

$P_{z}$ - dawka roczna izotopu na głębokości $z$ [atomy $\cdot \mathrm{g}^{-1} \cdot \operatorname{rok}^{-1}$ ]; $\lambda$ - stała rozpadu promieniotwórczego izotopu $\left[\mathrm{rok}^{-1}\right]$;

$\varepsilon$-tempo erozji stropu osadów po ich odsłonięciu $\left[\mathrm{cm} \cdot \mathrm{rok}^{-1}\right]$; $\rho$ - gęstość osadu $\left[\mathrm{g} \cdot \mathrm{cm}^{-3}\right]$;

$\Lambda$ - współczynnik osłabienia strumienia promieniowania wraz z głębokością $\left[\mathrm{g} \cdot \mathrm{cm}^{-2}\right]$;

$t$ - czas [lata];

$C_{i n h}-$ koncentracja izotopów odziedziczonych po wcześniejszych epizodach ekspozycji.

Oprócz dawki rocznej kluczowe znaczenie dla koncentracji izotopu na danej głębokości w profilu osadów mają zatem: liczba atomów odziedziczona po epizodach ekspozycji osadów wcześniejszych niż ostatnia deglacjacja $\left(C_{i n h}\right)$, tempo erozji profilu $(\varepsilon)$, stała rozpadu promieniotwórczego izotopu $(\lambda)$ i czas ekspozycji badanej warstwy $(t)$. Kwestia odziedziczenia atomów po wcześniejszych epizodach ekspozycji wynika z możliwości przetrwania w osadzie ziaren kwarcu, które zawierają część izotopów zakumulowanych podczas ewentualnych ekspozycji na promieniowanie kosmiczne przed inkorporacją skał do transportu glacjalnego, tj. przed pobraniem ich przez lądolód - dotyczy to głównie nuklidów o długim czasie połowicznego rozpadu. Takie nuklidy mogą przetrwać okres transportu i depozycji pod lądolodem bez istotnego spadku ich zawartości w osadzie. Oddziaływanie erozji podczas transportu skał i osadu w lądolodzie powoduje ścieranie powierzchni klastów i ziaren mineralnych oraz usuwanie zakumulowanych w nich nuklidów kosmogenicznych (np. Matthews i in., 2017). Jednak nie w każdych warunkach erozja glacjalna oddziałuje w sposób efektywny (dotyczy to np. zimnego reżimu termicznego stopy lądolodu). Co więcej, mniejsze ziarna w osadzie (np. drobny żwir i piasek) mogą być produktem ścierania powierzchni większych fragmentów skalnych i w konsekwencji zazwyczaj zawierają one izotopy odziedziczone.

W uproszczonym scenariuszu, który zakłada brak nuklidów odziedziczonych oraz zerową erozję profilu, krzywe koncentracji radioizotopów kosmogenicznych
${ }^{10} \mathrm{Be},{ }^{26} \mathrm{Al} \mathrm{i}{ }^{14} \mathrm{C}$ w warstwie gliny odsłoniętej spod lądolodu 20 tys. lat temu będą obrazować ich wykładniczy spadek i prawie zupełny zanik na głębokości ok. $300 \mathrm{~cm}$ (ryc. 3A). W takim przypadku wzór [2] przyjmuje prostszą postać bez komponentu odziedziczonego $\left(C_{i n h} e^{-\lambda t}\right)$ oraz wyrażenia opisującego erozję profilu $\left(\rho \varepsilon \cdot \Lambda^{-I}\right)-\mathrm{w}$ której pozostaje tylko jedna niewiadoma, jaką jest czas $(t)$. W takiej sytuacji określenie czasu ekspozycji warstwy gliny wymaga jedynie rozwiązania wzoru dla zmiennej $t$ na podstawie pomiaru koncentracji radionuklidu kosmogenicznego w stropie osadów, jego powierzchniowej dawki rocznej, skalowanej do szerokości geograficznej i wysokości bezwzględnej miejsca poboru próbki (Dunai, 2010) oraz stałej rozpadu promieniotwórczego. Sprowadza się to do prostego datowania ekspozycji powierzchni osadów, analogicznie jak w przypadku wykorzystania eratyków lub wychodni skalnych do datowania zaniku lodowców i lądolodów (Ivy-Ochs, Briner, 2014).

W rzeczywistości zupełny brak nuklidów odziedziczonych oraz erozji stropu gliny podczas jej ekspozycji po zlodowaceniu występuje niezwykle rzadko. Zazwyczaj osad zawiera nuklidy odziedziczone, a jego profil uległ bądź wciąż ulega erozji w rezultacie oddziaływania czynników niszczących w warunkach subaeralnych (Anderson i in., 1996; Wüthrich i in., 2017). W takim przypadku wzór [2] oprócz czasu ekspozycji $(t)$, będzie zawierać jeszcze dwie niewiadome: zawartość nuklidów odziedziczonych $\left(C_{i n h}\right)$ i tempo erozji profilu $(\varepsilon)$.

W analizowanym scenariuszu krzywe koncentracji radioizotopów kosmogenicznych ${ }^{10} \mathrm{Be},{ }^{26} \mathrm{Al} \mathrm{i}{ }^{14} \mathrm{C}$ w warstwie gliny odsłoniętej spod lądolodu 20 tys. lat temu, ulegającej od tego czasu erozji w jednostajnym tempie $2 \mathrm{~cm}$ na tysiąc lat oraz zawierającej nuklidy odziedziczone po przykładowo 10 tys. lat wcześniejszej ekspozycji, również będą wykazywać wykładniczy spadek wraz ze wzrostem głębokości. Jednakże na głębokości ok. $300 \mathrm{~cm}$ spadek ten będzie już znikomy i profile koncentracji izotopów będą się asymptotycznie zbliżać do pewnych stałych wartości, które możemy odnieść do zawartości izotopów odziedziczonych (Dortz i in., 2012). Koncentracja izotopów odziedziczonych jest więc de facto zawartością atomów danego nuklidu, jaką stwierdzimy w profilu na głębokości, na której wpływ promieniowania kosmicznego dochodzącego $\mathrm{z}$ powierzchni terenu jest już znikomy. Jeżeli zatem izotopy kosmogeniczne występują tak głęboko w profilu glin, to mogą one pochodzić z epizodów wcześniejszych ekspozycji, na które były wystawione źródłowe ziarna osadu lub sam osad przed pokryciem go przez lądolód. W konsekwencji zawartość nuklidów odziedziczonych możemy określić poprzez analizę próbek pobranych $\mathrm{w}$ zadanym interwale pionowym $\mathrm{z}$ odpowiednio miąższego profilu osadu ( $\geq 300 \mathrm{~cm})$, odnosząc poziom odziedziczenia do koncentracji nuklidów, która już nie ulega istotnej zmianie pomimo wzrostu głębokości (ryc. 3B).

Kluczowy wpływ na udział izotopów odziedziczonych w ogólnej koncentracji radionuklidów kosmogenicznych ma czas odcięcia osadu od oddziaływania promieniowania kosmicznego oraz okres połowicznego rozpadu analizowanego izotopu. Nuklidy o krótkim okresie połowicznego rozpadu (np. ${ }^{14} \mathrm{C}-5730$ lat) stosunkowo szybko ulegaja zanikowi i ich zawartość w formie odziedziczonej jest zazwyczaj bardzo mała lub nawet trudna do wykrycia (ryc. 3B). W przypadku nuklidów o zdecydowanie dłuższym okresie połowicznego rozpadu (np. ${ }^{10} \mathrm{Be}-1,387 \mathrm{mln}$ lat $\mathrm{i}{ }^{26} \mathrm{Al}-$ 0,717 mln lat) należy uwzględnić, jaka część ich zawartości w profilu gliny została odziedziczona i wtedy we wzorze 


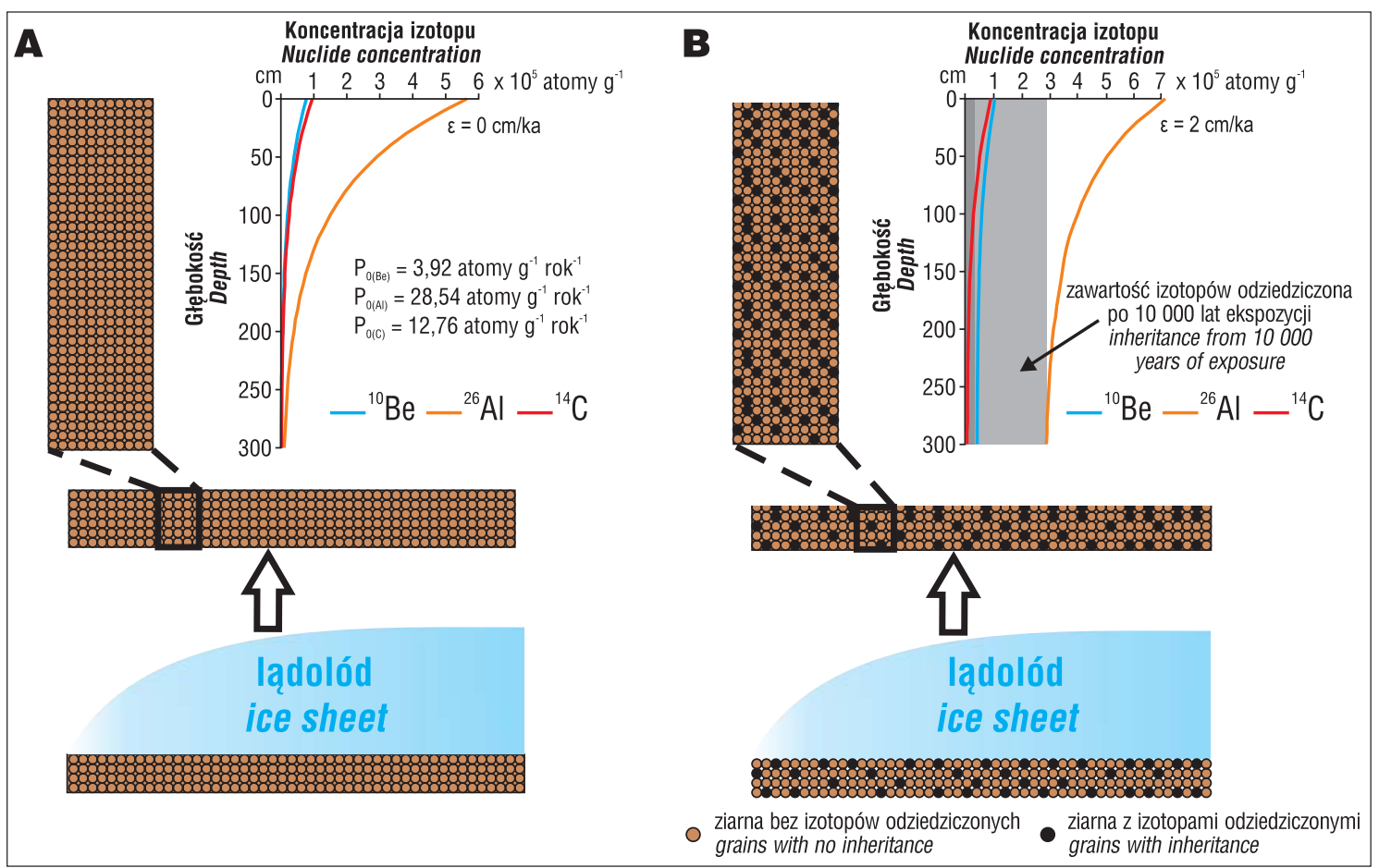

Ryc. 3. Profile koncentracji izotopów kosmogenicznych powstających w kwarcu $\left({ }^{26} \mathrm{Al},{ }^{10} \mathrm{Be} \mathrm{i}^{14} \mathrm{C}\right) \mathrm{w}$ warstwie osadu o gęstości typowej dla glin lodowcowych $\left(2,2 \mathrm{~g} \cdot \mathrm{cm}^{-3}\right)$ po 20 tys. lat ciagłej ekspozycji. Koncentracja izotopów na danej głębokości została określona na podstawie wzoru przedstawionego $\mathrm{w}$ tekście. Założono osłabienie strumienia promieniowania kosmicznego wraz z głębokością na poziomie $160 \mathrm{~g} \cdot \mathrm{cm}^{-2}: \mathbf{A}$ - brak nuklidów odziedziczonych i erozji stropu gliny; B - zawartość nuklidów odziedziczonych odpowiadająca 10 tys. lat wcześniejszej ekspozycji części ziaren oraz erozja stropu gliny po jej odsłonięciu w tempie $2 \mathrm{~cm}$ na tys. lat

Fig. 3. Profiles of cosmogenic nuclides concentration in quartz $\left({ }^{26} \mathrm{Al},{ }^{10} \mathrm{Be}\right.$ and $\left.{ }^{14} \mathrm{C}\right)$ in a layer of deposits with density typical for till $\left(2.2 \mathrm{~g} \cdot \mathrm{cm}^{-3}\right)$ and after 20,000 years of continuous exposition. Concentration of nuclides at certain depth was calculated based on the formula explained in the text and parameters presented in this Figure. The attenuation length of $160 \mathrm{~g} \cdot \mathrm{cm}^{-2}$ was assumed: $\mathbf{A}$ - no inheritance and no till erosion at the top; $\mathbf{B}$ - amount of inherited nuclides from 10,000 years of exposure of part of grains, and till erosion at the top after exposure at a rate of $2 \mathrm{~cm}$ per 1,000 years

[2] pozostają tylko dwie niewiadome: czas $(t)$ oraz tempo erozji (ع). Najbardziej prawdopodobny czas ekspozycji gliny na promieniowanie można $\mathrm{w}$ takiej sytuacji określić poprzez dopasowanie modelowej krzywej, która najlepiej odzwierciedla zmianę zawartości nuklidów w profilu, określoną na podstawie pomiarów wykonanych na próbkach pobranych w odpowiednim interwale pionowym. Dopasowanie krzywej (optymalizację parametrów funkcji) można przeprowadzić np. poprzez aproksymację zmienności nieliniowej metodą najmniejszych kwadratów (Granger, Smith, 2000) lub też poprzez wielokrotne próbkowanie czasu $(t)$ i tempa erozji $(\varepsilon)$ metodą symulacji Monte-Carlo (Hidy i in., 2010). Umożliwia to znalezienie takiego czasu ekspozycji i tempa erozji, dla których modelowana krzywa będzie najlepiej dopasowana do pomiarów, a więc będzie odzwierciedlać zmianę koncentracji badanego radionuklidu w profilu gliny. Najbardziej prawdopodobny wiek ekspozycji warstwy gliny, a więc czas, który upłynął od momentu jej finalnej depozycji, jest w rezultacie czasem $(t)$, jaki otrzymujemy jako wynik modelowania krzywej.

\section{Czas pogrzebania glin}

Analiza koncentracji w profilach glin pary izotopów kosmogenicznych o różnym oraz wystarczająco długim czasie połowicznego rozpadu (np. ${ }^{26} \mathrm{Al} \mathrm{i}{ }^{10} \mathrm{Be}$ ) umożliwia datowanie pogrzebania tych osadów. W ten sposób datuje się zazwyczaj osady stożków aluwialnych, tarasów rzecz- nych czy osadów wodnolodowcowych, które powstały w efekcie stosunkowo szybkiej i nagłej akumulacji (m.in. Granger, Smith, 2000; Häuselman i in., 2007; Darvill i in., 2015). Gliny bazalne można datować tą metodą w sytuacji, gdy w analizowanym profilu występują kopalne osady niezredukowane erozyjnie, z zachowaną oryginalną powierzchnią (np. poziomem gleby kopalnej), przykryte kolejną warstwą gliny. Wyniki datowania tego typu osadów metodami luminescencyjnymi są problematyczne ze względu na wysokie prawdopodobieństwo niekompletnego wygaszenia ziaren (tzn. wyzerowania sygnału luminescencyjnego w efekcie oddziaływania światła). Ponadto metoda izotopów kosmogenicznych oferuje o wiele większy przedział czasowy datowania niż metody luminescencyjne, sięgający milionów lat (np. Davis i in., 2011).

Do datowania pogrzebania osadów na podstawie analizy stosunku koncentracji pary izotopów kosmogenicznych wykorzystuje się fakt, iż podczas ekspozycji osadu na wtórne promieniowanie kosmiczne nuklidy tworzą się $\mathrm{w}$ określonym tempie, związanym z ich dawką roczna, a po odcięciu osadu od promieniowania kosmicznego ich zawartość w osadzie ulega zmniejszeniu zgodnie ze stała połowicznego rozpadu danego radionuklidu. W związku z tym całkowite odcięcie osadu od promieniowania kosmicznego powoduje, iż izotopy kosmogeniczne zakumulowane w kwarcu zaczynają zanikać zgodnie z cechującym je czasem połowicznego rozpadu, więc ich stosunki ulegają zmianie wraz z upływającym czasem pogrzebania osadu (Gosse, 
Philips, 2001; Granger, Muzikar, 2001). W osadach, które przez dziesiątki tysięcy lat były eksponowane na działanie promieniowania kosmicznego, stosunek powstających $\mathrm{w}$ kwarcu izotopów ${ }^{26} \mathrm{Al}$ do ${ }^{10} \mathrm{Be}$ wynika $\mathrm{z}$ różnego tempa ich produkcji i wynosi 7,2 (Borchers i in., 2016). Okres połowicznego rozpadu ${ }^{10} \mathrm{Be}(1,387 \mathrm{mln}$ lat $)$ jest około dwukrotnie dłuższy niż okres połowicznego rozpadu ${ }^{26} \mathrm{Al}$ $(0,717 \mathrm{mln}$ lat $)$, stąd też zanikają one $\mathrm{w}$ różnym tempie.

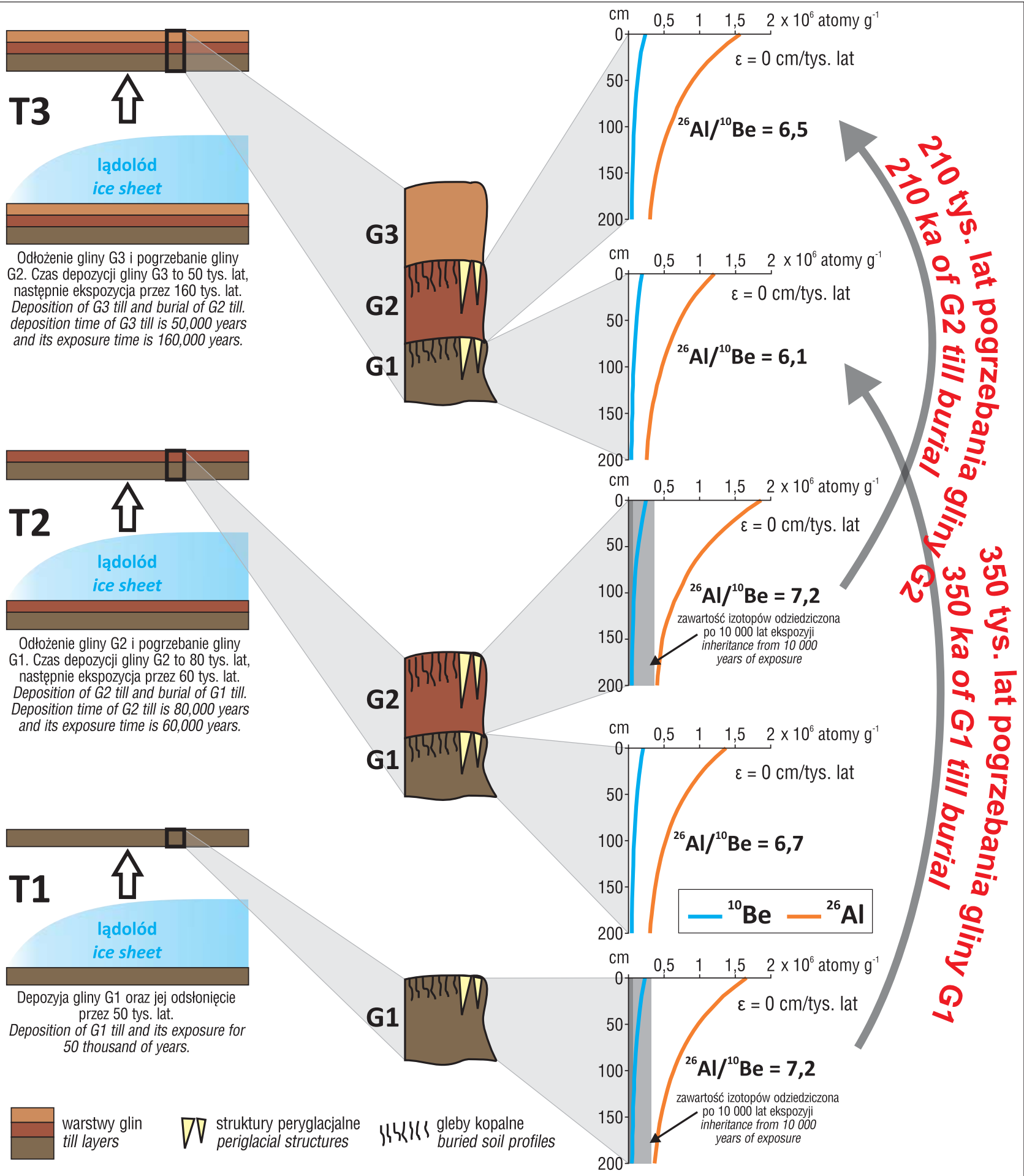

Ryc. 4. Schemat datowania glin bazalnych z wykorzystaniem pary ziemskich izotopów kosmogenicznych ${ }^{26} \mathrm{Al} \mathrm{i}{ }^{10} \mathrm{Be}$ oraz techniki burial dating. Scenariusz zdarzeń zakłada powstanie trzech warstw glin bazalnych (G1, G2 i G3) oraz gleb kopalnych lub też struktur peryglacjalnych w rezultacie trzech epizodów depozycji i ekspozycji glin (T1, T2 i T3). Założony czas trwania epizodów został opisany pod rycinami obrazującymi depozycję glin pod lądolodem. Profile koncentracji ${ }^{26} \mathrm{Al} \mathrm{i}{ }^{10} \mathrm{Be}$ po poszczególnych epizodach zostały wykreślone przy założeniu gęstości gliny $2,2 \mathrm{~g} \cdot \mathrm{cm}^{-3}$ oraz osłabienia strumienia promieniowania kosmicznego wraz z głębokością na poziomie $160 \mathrm{~g} \cdot \mathrm{cm}^{-2}$

Fig. 4. Mechanism of basal till burial dating with paired in situ cosmogenic nuclides ${ }^{26} \mathrm{Al}$ and ${ }^{10} \mathrm{Be}$. The scenario assumes formation of three basal till layers (G1, G2 and G3), buried soils or periglacial structures as a result of three episodes of till deposition and exposition (T1, T2 and T3). The time assumed for each episode was described in this Figure. Profiles of ${ }^{26} \mathrm{Al}$ and ${ }^{10} \mathrm{Be}$ concentration after each episode were created based on till density of $2.2 \mathrm{~g} \cdot \mathrm{cm}^{-3}$ and attenuation length of $160 \mathrm{~g} \cdot \mathrm{cm}^{-2}$ 
Schemat datowania warstw gliny bazalnej na podstawie analizy par ziemskich izotopów kosmogenicznych powstających w kwarcu obrazuje ryc. 4 . W przyjętym scenariuszu (ryc. 4) założono depozycję trzech warstw glin bazalnych (G1, G2 i G3) podczas trzech epizodów depozycji i ekspozycji osadów (T1, T2 i T3). Najstarsza warstwa gliny (G1) została odłożona podczas pierwszego nasunięcia lądolodu, a po jego recesji była eksponowana na działanie wtórnego promieniowania kosmicznego przez 50 tys. lat (T1). Podczas okresu ekspozycji w ziarnach kwarcu znajdujących się w glinie powstawały nuklidy ${ }^{26} \mathrm{Al} \mathrm{i}{ }^{10} \mathrm{Be}$ w tempie będącym wypadkową ich dawek rocznych na określonej głębokości i czasu połowicznego rozpadu (ryc. 4). Strop gliny ulegał bardzo niewielkiej erozji, czego dowodem moga być zachowany poziom gleby kopalnej lub też horyzont struktur peryglacjalnych, będące zapisem okresu ekspozycji gliny. Stosunek izotopów ${ }^{26} \mathrm{Al} /{ }^{10} \mathrm{Be}$ ustalił się na poziomie $\sim 7,2$, który charakteryzuje ich różne tempo produkcji (dawkę roczną).

W następnym epizodzie (T2) glina G1 została przykryta przez nasuwający się lądolód, który rozpoczął odkładanie gliny G2. W tym momencie glina G1 została odcięta od wpływu wtórnego promieniowania kosmicznego i moment transgresji lądolodu, który odłożył glinę G2, jest tu równoczasowy z momentem pogrzebania gliny G1 (ryc. 4). Od momentu pogrzebania gliny G1 (epizod T2) powstawanie w niej nuklidów ${ }^{26} \mathrm{Al}{ }^{10}$ Be zostało zahamowane $\mathrm{i}$ ich koncentracja w profilu zaczęła się zmieniać zgodnie z czasem ich połowicznego rozpadu. Po epizodzie T2, obejmującym 80 tys. lat depozycji gliny $\mathrm{G} 2$ oraz jej ekspozycję po recesji lądolodu przez kolejne 60 tys. lat, stosunek ${ }^{26} \mathrm{Al} /{ }^{10} \mathrm{Be} \mathrm{w}$ glinie G1 zmalał do $\sim 6,7$. Jednocześnie $\mathrm{w}$ glinie $\mathrm{G} 2$ podczas 60 tys. lat ekspozycji powstały izotopy kosmogeniczne ${ }^{26} \mathrm{Al} \mathrm{i}{ }^{10} \mathrm{Be}$ (ryc. 4).

Epizod T3 to depozycja oraz ekspozycja trzeciej, najmłodszej warstwy gliny (G3). Transgresję lądolodu, który odłożył glinę G3, można odnieść do momentu pogrzebania gliny G2 i odcięcia jej od wpływu promieniowania kosmicznego. Depozycja najmłodszej gliny trwała 50 tys. lat, a jej ekspozycja po ostatecznym ustapieniu lądolodu 160 tys. lat. Spowodowało to dalszy spadek stosunku nuklidów ${ }^{26} \mathrm{Al} /{ }^{10} \mathrm{Be}-\mathrm{w}$ glinie $\mathrm{G} 1$ do $\sim 6,1$, a w glinie $\mathrm{G} 2$ do $\sim 6,5$ (ryc. 4). Analizując zmiany stosunku ${ }^{26} \mathrm{Al} /{ }^{10} \mathrm{Be}$ w glinie G1 można więc określić wiek jej pogrzebania, który jest równoznaczny z czasem, jaki upłynął od nasunięcia lądolodu, który odłożył glinę G2, do dziś. Zmiany stosunku ${ }^{26} \mathrm{Al} /{ }^{10} \mathrm{Be} w$ glinie $\mathrm{G} 2$ również wskazują na wiek jej pogrzebania, który jest z kolei równoznaczny z czasem, jaki upłynął od transgresji lądolodu, który odłożył glinę G3, do dziś. Zawartość analizowanych radionuklidów w profilu gliny G1 wskazuje zatem na moment transgresji lądolodu odkładającego glinę G2, natomiast ich zawartość w profilu gliny G2 wskazuje na moment transgresji lądolodu odkładającego glinę G3.

Zastosowanie pary izotopów kosmogenicznych o różnym okresie połowicznego rozpadu do datowania glin w profilach osadów z zachowanym oryginalnym stropem, które zostały przykryte gliną bazalną, pozwala zatem na datowanie prawdopodobnego początku depozycji gliny (Fabel, Harbor, 1999). Wyniki tego typu datowania wskazują bezpośrednio na moment nasunięcia lądolodu, natomiast datowanie czasu ekspozycji glin na promieniowanie dostarcza informacji o czasie recesji lądolodu. Analiza zawartości ziemskich izotopów kosmogenicznych w profilach glin umożliwia więc określenie czasu nasunięć oraz recesji lądolodów.

\section{PRZYKLAD DATOWANIA GLIN METODĄ IZOTOPÓW KOSMOGENICZNYCH}

Pionierem w stosowaniu metody izotopów kosmogenicznych do określania chronologii etapów akumulacji warstw glin lodowcowych jest Balco $i$ in. (2005a, b, c). Główną motywacją do podjęcia tego typu badań była możliwość określenia wieku glin, których szacunkowa pozycja stratygraficzna znacznie przekracza zakres czasowy metody radiowęglowej i metod luminescencyjnych. Balco i in. (2005a, b, c) badaniom poddali profil osadów zlokalizowany w środkowej części Ameryki Północnej, w strefie maksymalnego zasięgu ostatniego lądolodu laurentyjskiego. Obejmuje on warstwę lessów o miąższości $2 \mathrm{~m}$, dwie warstwy glin (formacji Moberly i Atlanta o łącznej miąższości $18 \mathrm{~m}$ ), a także koluwium formacji Whippoorwill o miąższości ok. 1,5 m. Osady te zalegają na podłożu skał węglanowych. Próbki pobrano z profili gleb kopalnych rozwiniętych w formacjach Whipporwill oraz Atlanta (ryc. 5). Następnie poddano je standardowej procedurze preparatyki do pomiarów zawartości izotopów ${ }^{26} \mathrm{Al} \mathrm{i}{ }^{10} \mathrm{Be}$ w kwarcu z wykorzystaniem atomowej spektrometrii mas (Kohl, Nishiizumi, 1992). Wyniki pomiarów posłużyły do kalkulacji czasu pogrzebania glin na podstawie założeń techniki burial dating. Aby było to możliwe, badacze stworzyli model wiek/głębokość, obrazujący głębokość pogrzebania warstwy osadów względem kolejnych epizodów sedymentacji i ekspozycji (ryc. 5). Oszacowanie wieku glin w latach wymagało określonych założeń oraz przekształceń modelu, co w efekcie zaowocowało funkcją tempa produkcji nuklidów w czasie $P(t)$ i możliwością predykcji bieżącej koncentracji nuklidów w osadzie dla dowolnego nuklidu i poziomu pogrzebania, przy założeniu $t \in\left[0, t_{1}+t_{2}+t_{3}\right]$ dla starszej formacji Whippoorwill oraz $t \in\left[t_{1}, t_{1}+t_{2}+t_{3}\right]$ dla młodszej formacji Atlanta (Balco i in., 2005a):

$$
\frac{d N_{j}}{d t}=P_{j}(t)-N_{j} \lambda_{j}
$$

gdzie:

$N_{j}$ - koncentracja nuklidu $j \mathrm{w}$ kwarcu [atomy $\cdot \mathrm{g}^{-1}$ ];

$P_{j}(t)$ - tempo produkcji nuklidu $j$ w czasie $t$ [atomy $\cdot \mathrm{g}^{-1}$. rok $\left.^{-1}\right]$

$\lambda_{j}-$ stała rozpadu nuklidu $j$.

Warunki początkowe zostały ustalone następująco:

$$
\left\{\begin{array}{l}
N_{w, j}=\frac{P_{j, 0}}{\lambda+\frac{\varepsilon_{w}}{\Lambda}}, \text { dla } t=0 \\
N_{a, j}=\frac{P_{j, 0}}{\lambda_{j}+\frac{\varepsilon_{a}}{\Lambda}}, \text { dla } t=t_{1}
\end{array}\right.
$$

gdzie:

$w$ - formacja Whippoorwill;

$a$ - formacja Atlanta;

$P_{j, 0}$ - tempo produkcji nuklidu $j$ na powierzchni Ziemi; 


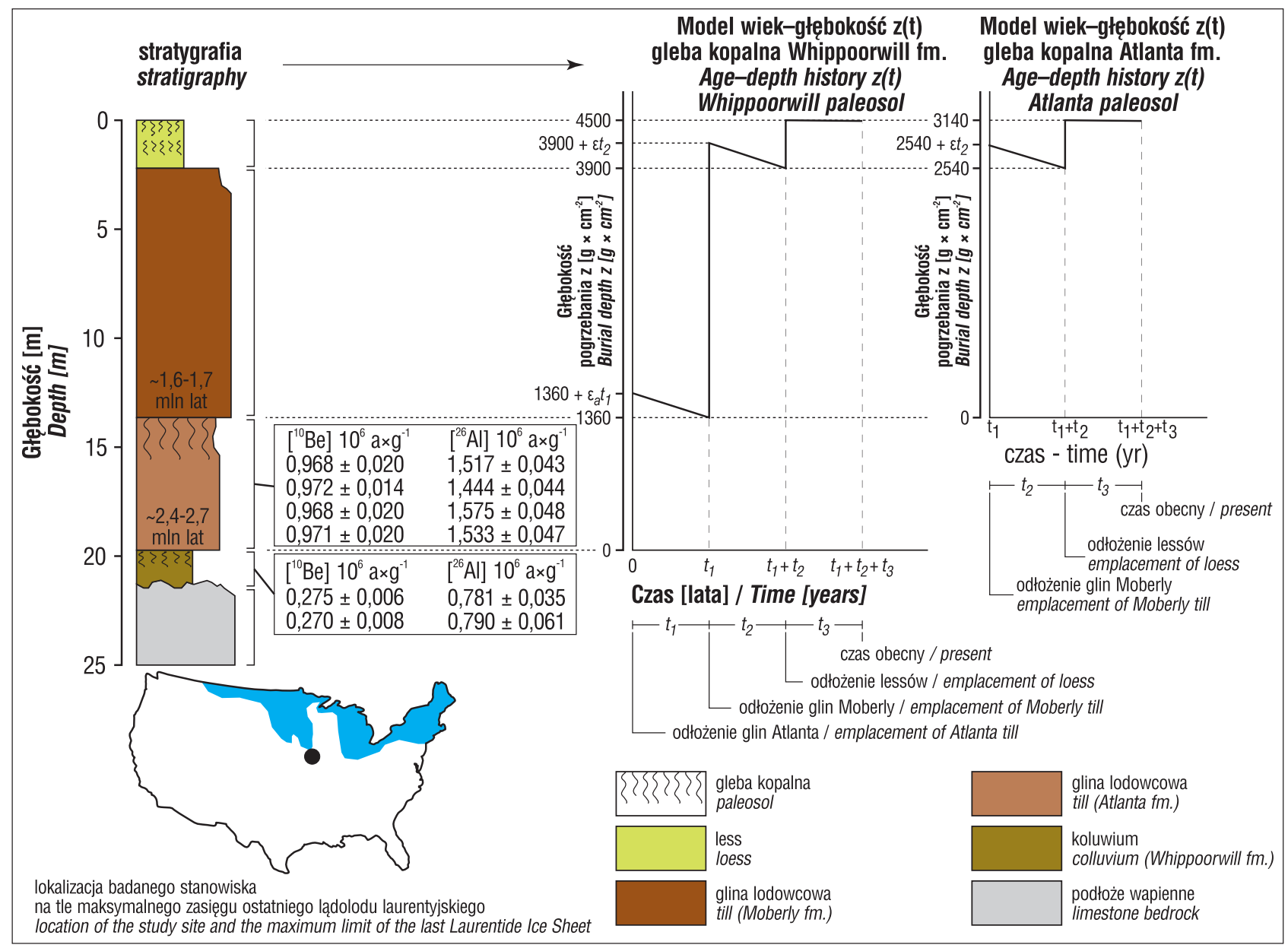

Ryc. 5. Ilustracja pierwszej próby bezpośredniego określenia wieku glin lodowcowych na podstawie izotopów kosmogenicznych (Balco i in., 2005a; zmieniona). Zgoda na reprodukcję ryciny z czasopisma Science via CCC-4776950815157

Fig. 5. Illustration of the first studies in till dating with in situ cosmogenic nuclides (Balco et al., 2005a; modified). Permission for figure reproduction from Science magazine via CCC-4776950815157

$\Lambda$ - współczynnik osłabienia strumienia promieniowania wraz z głębokością $\left[160 \mathrm{~g} \cdot \mathrm{cm}^{-2}\right]$;

$\varepsilon$ - tempo erozji profilu przed pogrzebaniem $\left[0,001 \mathrm{~g} \cdot \mathrm{cm}^{-2}\right.$ $\left.\cdot \operatorname{rok}^{-1}\right]$.

Na podstawie lokalnej stratygrafii przyjęto, że wiek depozycji i ekspozycji lessów $\left(t_{3}\right)$ wynosi ok. 125 tys. lat. Następnie, uwzględniając koncentrację izotopów ${ }^{26} \mathrm{Al} \mathrm{i}{ }^{10} \mathrm{Be}$, dokonano optymalizacji funkcji z czterema niewiadomymi: 1) czas, jaki upłynął od depozycji gliny formacji Atlanta do depozycji gliny formacji Moberly $\left.\left(t_{1}\right) ; 2\right)$ czas, jaki upłynął od depozycji gliny formacji Moberly do depozycji lessów $\left.\left(t_{2}\right) ; 3\right)$ tempo erozji koluwium formacji Whippoorwill $\left(\varepsilon_{w}\right)$ oraz 4$)$ tempo erozji gliny formacji Atlanta $\left(\varepsilon_{a}\right)$. $\mathrm{W}$ wyniku rozwiązania równania otrzymano: $t_{l}=0,61 \mathrm{mln}$ lat; $t_{2}=1,68 \mathrm{mln}$ lat; $\varepsilon_{w}=2,7 \cdot 10^{-4} \mathrm{~g} \cdot \mathrm{cm}^{-2} \cdot \operatorname{rok}^{-1} ; \varepsilon_{a}=1,8 \cdot 10^{-3} \mathrm{~g}$ $\cdot \mathrm{cm}^{-2} \cdot \mathrm{rok}^{-1}$. Zgodnie z założeniami metody burial dating depozycja gliny formacji Atlanta spowodowała pogrzebanie gleby kopalnej rozwiniętej w stropie koluwium formacji Whippoorwill i nastapiło to $\mathrm{w}$ czasie $t_{1}+t_{2}+t_{3}=2,415 \mathrm{mln}$ lat, co (po interpretacji i uwzględnieniu błędu) dało wiek ok. 2,4-2,7 mln lat (Balco i in., 2005a, b, c), natomiast depozycja gliny formacji Moberly spowodowała pogrzebanie gleby kopalnej rozwiniętej w stropie gliny Atlanta w czasie $t_{2}+t_{3}=1,8 \mathrm{mln}$ lat temu, co (również po interpretacji i uwzględnieniu błędu) nastapiło ok. 1,6-1,7 mln lat temu
(Balco i in., 2005a, b, c). Niepewność otrzymanego wieku glin była uzależniona głównie od stałej rozpadu izotopów ${ }^{26} \mathrm{Al} \mathrm{i}{ }^{10} \mathrm{Be}$, natomiast inne czynniki, tj. niepewności analityczne czy dotyczace tempa produkcji analizowanych izotopów, nie wpłynęły w zasadniczy sposób na błąd oszacowania wieku ze względu na stosunkowo duże koncentracje izotopów w próbkach oraz pogrzebanie badanych profili gleb kopalnych przez miąższe warstwy osadów (ryc. 5).

Balco i in. (2005a) udowodnili, że transgresja lądolodu laurentyjskiego, najstarszego plejstoceńskiego lądolodu na kontynencie północnoamerykańskim, nastąpiła ok. 2,4-2,7 mln lat temu. Wiek badanych glin porównano z okresami ochłodzeń klimatu zapisanymi w osadach oceanicznych (rozpoznanymi na podstawie zmienności $\delta^{18} \mathrm{O}$, procentowej zawartości $\mathrm{CaCO}_{3} \mathrm{w}$ osadzie czy też jego podatności magnetycznej) i okazało się, że można je bardzo dobrze skorelować.

\section{POTENCJAL I OGRANICZENIA METODY}

Analiza koncentracji ziemskich izotopów kosmogenicznych $w$ glinach lodowcowych jest obecnie jedyną metodą, którą można stosować do bezpośredniego datowania tego typu osadów. W przeciwieństwie do stosowanej w przeszłości metody TL ma ona solidne podstawy fizyczne 
i uwzględnia specyfikę środowiska depozycji glin lodowcowych, które są odkładane pod lodem, a więc w warunkach odcięcia od wpływu światła słonecznego i promieniowania kosmicznego. Umożliwia ona modelowanie wieku glin w latach i rozwiązywanie wielu problemów stratygrafii plejstocenu oraz historii zlodowaceń. Za sprawą tej metody glina lodowcowa, stanowiąca dotąd jedynie bezpośredni i bezsprzeczny zapis obecności lądolodu, uzyskała nową, unikalną wartość w kontekście rekonstrukcji paleoklimatycznych, gdyż jej depozycja została powiązana ze skalą czasu. W związku z tym zastosowanie izotopów kosmogenicznych do datowania glin lodowcowych może przyczynić się do rozwiązania zagadek stratygrafii czwartorzędu oraz problemów zmian paleoklimatu w ciągu 2 ostatnich mln lat. Ma to szczególne znaczenie w odniesieniu do glin uformowanych we wczesnym i środkowym plejstocenie, gdyż określenie ich wieku nie jest możliwe nawet poprzez datowanie współwystępujących osadów piaszczystych metodą OSL, ze względu na zasięg czasowy tej metody, ograniczony zazwyczaj do ok. 150 tys. lat (Wallinga, Cunnigham, 2015).

Metoda datowania glin lodowcowych na podstawie zawartości ziemskich izotopów kosmogenicznych, mimo znacznego potencjału, ma również wiele ograniczeń, które trzeba brać pod uwagę w trakcie jej stosowania i interpretacji wyników. Są one związane z uwarunkowaniami geologicznymi, które muszą zostać spełnione, aby wyniki badań były wiarygodne i stanowiły źródło rzetelnej dyskusji.

W celu określenia czasu ekspozycji gliny należy wybrać jej powierzchniową warstę o miąższości przynajmniej $3 \mathrm{~m}$, aby z profilu koncentracji nuklidów można było wywnioskować koncentrację izotopów odziedziczonych. Ponadto dokładność modelowania wieku gliny znajdującej się na powierzchni terenu istotnie zależy od tego, czy znane jest tempo erozji jej stropu, czy też jest ono jedną z dwóch niewiadomych ( $t$ i $\varepsilon$ ). Dlatego większy potencjał badawczy, umożliwiający dokładne określenie czasu ekspozycji gliny, który można interpretować jako okres, jaki upłynął od deglacjacji, mają te profile, w których na podstawie niezależnych przesłanek, np. sedymentologicznych lub gleboznawczych, można oszacować tempo erozji.

Jeśli celem badań jest określenie czasu pogrzebania warstw gliny, do datowania należy wytypować profile glin, w których występują dowody świadczące o zachowaniu niezerodowanego stropu osadów (np. w profilu są obecne poziomy gleb kopalnych lub horyzonty struktur peryglacjalnych). Niestety, na skutek erozji warstwy osadów plejstoceńskich bardzo często są pozbawione stropowych partii i zachowane jedynie fragmentarycznie, a pełne ich profile są rzadkością. Warto też zwrócić uwagę na to, że obecność niektórych struktur peryglacjalnych (np. klinów mrozowych) nie gwarantuje zachowania pełnego profilu osadów, a może jedynie wskazywać na ograniczony wpływ erozji na ich strop. Gleby kopalne są zatem pewniejszym wskaźnikiem zachowania oryginalnego stropu osadów, choć ich występowanie pod glinami lodowcowymi jest zjawiskiem bardzo rzadkim. Ponadto, wiarygodne wyniki datowań można uzyskać tylko wówczas, gdy miąższość glin w profilu jest na tyle duża, żeby depozycja kolejnej warstwy gliny powodowała całkowite zahamowanie produkcji izotopów kosmogenicznych w warstwie leżącej poniżej. Oznacza to, że powinno się analizować warstwy glin o miąższości co najmniej $3 \mathrm{~m}$, pokrywające niezerodowane osady z za- chowaną pierwotną powierzchnią. Mogą to być profile jednej warstwy gliny, która spełnia wymienione kryteria, lub też profile sekwencji glin, jak w scenariuszu założonym w niniejszym artykule (ryc. 4). Zatem kluczowe dla powodzenia badań jest znalezienie i wytypowanie odpowiednich profili glin lodowcowych. Profile, w których występują gliny o miąższości mniejszej niż $3 \mathrm{~m}$ i nie zawierają form świadczących o zachowaniu pierwotnej powierzchni warstw lub też kontakty pomiędzy warstwami maja genezę erozyjną, nie powinny być brane pod uwagę.

Mimo wielu istotnych ograniczeń analiza zawartości ziemskich izotopów kosmogenicznych ma znaczący potencjał w datowaniu glin lodowcowych i jej zastosowanie do badania osadów czwartorzędowych może znacznie poszerzyć naszą wiedzę na temat chronologii procesów glacjalnych. Metoda ta była, jak dotąd, sporadycznie stosowana w Ameryce Północnej i Europie (Balco i in., 2005a, b, c; Wüthrich i in., 2017). Autorzy uważają, że wykorzystanie jej do badań z zakresu geologii czwartorzędu i geomorfologii na polskich stanowiskach może się przyczynić do rozwiązania wielu problemów i udzieli odpowiedzi na pytania od lat nurtujące badaczy czwartorzędu w naszym kraju.

Dziękujemy Recenzentom za krytyczne i konstruktywne uwagi oraz wiele pytań i wątpliwości, które przyczyniły się do poprawienia tekstu. Artykuł został przygotowany w ramach realizacji grantu Narodowego Centrum Nauki MINIATURA nr 2019/03/X/ST10/00930.

\section{LITERATURA}

ALEXANDERSON H., MURRAY A.S. 2009 - Problems and potential of OSL dating Weichselian and Holocene sediment in Sweden. Quatern. Sci. Rev., 44: 37-50.

ANDERSON R.S., REPKA J.L., DICK G.S. 1996 - Explicit treatment of inheritance in dating depositional surfaces using in situ ${ }^{10} \mathrm{Be}$ and ${ }^{26} \mathrm{Al}$. Geology, 24: 47-51.

BALCO G., ROVEY II C.W. 2008 - An isochron method for cosmogenic-nuclide dating of buried soils and sediments. Am. J. Sci., 308: 1083-1114.

BALCO G., ROVEY II, C.W., STONE J.O. 2005a - The first glacial maximum in North America. Science, 307: 222.

BALCO G., STONE J.O.H., JENNINGS C. 2005b - Dating Plio-Pleistocene glacial sediments using the cosmic-ray-produced radionuclides ${ }^{10} \mathrm{Be}$ and ${ }^{26}$ Al. Am. J. Sci., 305: 1-41.

BALCO G., STONE J.O.H., MASON J.A. 2005c - Numerical ages for Plio-Pleistocene glacial sediment sequences by ${ }^{26} \mathrm{Al} /{ }^{10} \mathrm{Be}$ dating of quartz in buried paleosols. Earth and Planetary Sci. Lett., 232: 179-191.

BENEDETTI L.C., WOERD J. 2014 - Cosmogenic Nuclide Dating of Earthquakes, Faults, and Toppled Blocks. Elements, 10: 357-361.

BLUSZCZ A . 2000 - Datowanie luminescencyjne osadów czwartorzędowych - teoria, ograniczenia, problemy interpretacyjne. Zesz. Nauk. Politechniki Śląskiej, Ser. Matematyka-Fizyka, 86, Geochronometria, 17: 104.

BORCHERS B., MARRERO S., BALCO G., CAFFEE M., GOEHRING B., LIFTON N., NISHIIZUMI K., PHILIPS F., SCHAEFER J., STONE J. 2016 - Geological calibration of spallation production rates in the CRONUS-Earth project. Quatern. Geochron., 31: 188-198.

BRINER J.P., LIFTON N.A., MILLER G.H., REFSNIDER K., ANDERSON R., FINKEL R. 2014 - Using in situ cosmogenic ${ }^{10} \mathrm{Be},{ }^{14} \mathrm{C}$, and ${ }^{26} \mathrm{Al}$ to decipher the history of polythermal ice sheets on Baffin Island, Arctic Canada. Quatern. Geochron., 19: 4-13.

CHRISTL M., WIELER R., FINKEL R.C. 2014 - Measuring one atom in a million billion with mass spectrometry. Elements, 10: 330-331.

CZERWONKA J.A. 2004 - Śląska i wielkopolska prowincja litostratygraficzna glin zwałowych. Prz. Geol., 52 (5): 421-429.

CZERWONKA J.A., DOBOSZ T., KRZYSZKOWSKI D. 1997 - Till stratigraphy of the northern part of Silesia (southwestern Poland). Geol. Quart., 41 (2): 209-242.

DARVILL C.M. 2013 - Cosmogenic nuclide analysis. [W:] Cook S.J., Clarke L.E., Nield J.M. (red.), Geomorphological Techniques. British Soc. Geomorph., London. 
DARVILL C.M., BENTLEY M.J., STOKES C.R., HEIN A.S., RODÉS Á 2015 - Extensive MIS 3 glaciation in southernmost Patagonia revealed by cosmogenic nuclide dating of outwash sediments. Earth and Planetary Sci. Lett., 429: 157-169.

DAVIS M., MATMON A., FINK D., RON H., NIEDERMANN S. 2011 Dating Pliocene lacustrine sediments in the central Jordan Valley, Israel Implications for cosmogenic burial dating. Earth and Planetary Sci. Lett., 305: 317-327.

DAVIS R., SCHAEFFER O.A. 1955 - Chlorine-36 in Nature. Ann. New York Acad. Sci., 62: 107-121.

DEHNERT A., SCHLÜCHTER C. 2008 - Sediment burial dating using terrestrial cosmogenic nuclides. E\&G Quatern. Sci. J., 57: 210-225.

DIXON J.L., RIEBE C.S. 2014 - Tracing and Pacing Soil Across Slopes. Elements, 10: 363-368.

DORTZ K.L., MEYER B., SÉBRIER M., BRAUCHER R., BOURLÈS D., BENEDETTI L., NAZARI H., FOROUTAN M. 2012 - Interpreting scattered in situ produced cosmogenic nuclide depth-profile data Quatern. Geochron., 11: 98-115.

DUNAI T. 2010 - Cosmogenic Nuclides: Principles, concepts and applications in the Earth surface sciences. Cambridge Univ. Press: 187.

EVANS D.J.A., PHILLIPS E.R., HIEMSTRA J.F, AUTON C.A. 2006 Subglacial till: Formation, sedimentary characteristics and classification. Earth Sci. Rev., 78: 115-176.

FABEL D., HARBOR J. 1999 - The use of in situ produced cosmogenic radionuclides in glaciology and glacial geomorphology. Ann. Glaciology, 28: 103-110.

FUCHS M., OWEN L.A. 2008 - Luminescence dating of glacial and associated sediments. Boreas, 37: 636-659.

GAŁĄZKA D., MARKS L., ZABIELSKI R. 1999 - Czy litostratygrafia glin lodowcowych może być przydatna dla stratygrafii czwartorzędu Polski? Prz. Geol., 47 (3): 261-265.

GOSSE J., PHILLIPS F. 2001 - Terrestrial in situ cosmogenic nuclides: theory and application. Quatern. Sci. Rev., 20: 1475-1560.

GRANGER D.E., MUZIKAR P.F. 2001 - Dating sediment burial with in situ-produced cosmogenic nuclides: theory, techniques, and limitations. Earth and Planetary Sci. Lett., 188: 269-281.

GRANGER D.E., SMITH A.L. 2000 - Dating buried sediments using radioactive decay and muogenic production of ${ }^{26} \mathrm{Al}$ and ${ }^{10} \mathrm{Be}$. Nuclear Instruments and Methods in Physics Res. B, 172: 822-826.

HAJDAS I., IVY-OCHS S., PICKERING R., PREUSSER F. $2008-$ Recent developments in Quaternary dating methods. Geographica Helvetica, 63: 176-180.

HARDT J., LÜTHGENS C., HEBENSTREIT R., BÖSE M. 2016 - Geochronological (OSL) and geomorphological investigations at the presumed Frankfurt ice marginal position in northeast Germany. Quatern. Sci. Rev. 154: 85-99.

HAÜSELMANN P.H.., FIEBIG M., KUBIK P.W., ADRIAN H. 2007 A first attempt to date the original "Deckenschotter" of Penck and Brückner with cosmogenic nuclides. Quatern. Intern., 164-165: 33-42. HEIN A.S, HULTON N.R.J., DUNAI T.J., SCHNABEL C., KAPLAN M.R., NAYLOR M., XU S. 2009 - Middle Pleistocene glaciation in Patagonia dated by cosmogenic-nuclide measurements on outwash gravels. Earth and Planetary Sci. Lett., 286: 184-197.

HIDY A.J., GOSSE J C., PEDERSON J. L., MATTERN J.P, FINKEL R. C. 2010 - A geologically constrained Monte Carlo approach to modeling exposure ages from profiles of cosmogenic nuclides: An example from Lees Ferry, Arizona, Geochemistry Geophysics Geosystems, 11: Q0AA10; doi.org/10.1029/2010GC003084

IVY-OCHS S., BRINER J.P. 2014 - Dating Disappearing Ice with Cosmogenic Nuclides. Elements, 10: 351-356.

IVY-OCHS S., HEUBERGER H., KUBIK P.W., KERSCHNER H., BONANI G., FRANK M., SCHLÜCHTER C. 1998 - The age of the Köfels event. Relative ${ }^{14} \mathrm{C}$ and cosmogenic isotope dating of an early Holocene landslide in the central Alps (Tyrol, Austria). Z. Gletscherkunde und Glazialgeol., 34: 57-68.

KLEIN J., GIEGENGACK R., MIDDLETON R., SHARMA P., UNDERWOOD J., WEEKS R.A. 1986 - Revealing histories of exposure using in situ produced ${ }^{26} \mathrm{Al}$ and ${ }^{10} \mathrm{Be}$ in Libyan desert glass. Radiocarbon, 28: 547-555.

KOHL C.P., NISHIIZUMI K. 1992 - Chemical isolation of quartz for measurement of in situ-produced cosmogenic nuclides. Geochim. Cosmochim. Acta, 56: 3583-3587.

LAL D. 1991 - Cosmic ray labeling of erosion surfaces: in situ nuclide production rates and erosion rates. Earth and Planetary Sci. Lett., 104: 424-439.

LINDNER L., SEMIL J., FEDOROWICZ S., OLSZAK I.J. 1989 - O braku wpływu skał podłoża na wiek TL glin zwałowych. Prz. Geol., 37 (3): 140-141.
LISICKI S. 2003 - Zasięgi lądolodu skandynawskiego w dorzeczu Wisły wyznaczone na podstawie petrograficznych badań glin lodowcowych, $\mathrm{w}$ nawiązaniu do izotopowych stadiów tlenowych. Prz. Geol., 51 (3): 217-223. LIU Y., WANG S., XU S., LIU X., FABEL D., ZHANG X., WEIJUN L., CHENG A. 2013 - New evidence for the incision history of the Liuchong River, Southwest China, from cosmogenic ${ }^{26} \mathrm{Al} /{ }^{10} \mathrm{Be}$ burial ages in cave sediments. J. Asian Earth Sci., 73: 274-283.

MASARIK J., REEDY R.C. 1995 - Terrestrial cosmogenic-nuclide production systematics calculated from numerical simulations. Earth and Planetary Sci. Lett., 136: 381-395.

MATTHEWS J.A., SHAKESBY R.A., FABEL D. 2017 - Very low inheritance in cosmogenic surface exposure ages of glacial deposits: A field experiment from two Norwegian glacier forelands. Holocene, 27: 1406-1414.

NISHIIZUMI K., FINKEL R.C., KLEIN J., KOHL C.P. 1996 - Cosmogenic production of ${ }^{7} \mathrm{Be}$ and ${ }^{10} \mathrm{Be}$ in water targets. J. Geophys. Res., 101: 22225-22232.

OLSZAK I.J., FLOREK W., SEUL C., MAJEWSKI M. 2008 - Stratygrafia i litologia mineralnych osadów występujących w klifach środkowej cześci polskiego wybrzeża Bałtyku. Landform Anal., 7: 113-118.

POTTER R., LI Y., HORN S.P., ORVIS K.H. 2019 - Cosmogenic Cl-36 surface exposure dating of late Quaternary glacial events in the Cordillera de Talamanca, Costa Rica. Quatern. Res., 92: 216-231.

PUTNAM A.E., BROMLEY G.R.M., RADEMAKER K., SCHAEFER J.M. 2019 - In situ ${ }^{10} \mathrm{Be}$ production-rate calibration from a ${ }^{14} \mathrm{C}$-dated late-glacial moraine belt in Rannoch Moor, central Scottish Highlands. Quatern. Geochron., 50: 109-125.

PRZEGIĘTKA K.R., CHRUŚCIŃSKA A., OCZKOWSKI H.L., MOLEWSKI P. 2008 - Chronostratigraphy of the Vistulian glaciation on the Kujawy moraine plateau (central Poland) based on lithostratigraphic research and OSL dating. Geochronometria, 32: 69-77.

RUSZKICZAY-RÜDIGER Z., BRAUCHER R., NOVOTHNY Á., CSILLAG G., FODOR L., MOLNÁR G., MADARẢSZ B. 2016 - Tectonic and climatic control on terrace formation: Coupling in situ produced ${ }^{10} \mathrm{Be}$ depth profiles and luminescence approach, Danube River, Hungary, Central Europe. Quatern. Sci. Rev., 131: 127-147.

SCHIMMELPFENNIG I., SCHAEFER J.M., GOEHRING B.M., LIFTON N., PUTNAM A.E., BARRELL D.J.A. 2012 - Calibration of the in situ cosmogenic ${ }^{14} \mathrm{C}$ production rate in New Zealand's Southern Alps. J. Quatern. Sci., 27: 671-674.

SOBCZYK A. 2016 - Zastosowanie ziemskich izotopów kosmogenicznych ${ }^{10} \mathrm{Be}{ }^{20} \mathrm{Al}$ w badaniach geologicznych - zarys metody oraz stan badań w Polsce. Biul. Państw. Inst. Geol., 466: 279-290.

SRINIVASAN B. 1976 - Barites - Anomalous xenon from spallation and neutron-induced reactions. Earth and Planetary Sci. Lett., 31: 129-141. TYLMANN K., RINTERKNECHT V.R., WOŹNIAK P.P., BOURLĖS D., SCHIMMELPFENNIG I., GUILLOU V., ASTER T. 2019 - The Local Last Glacial Maximum of the southern Scandinavian Ice Sheet front: Cosmogenic nuclide dating of erratics in northern Poland. Quatern. Scien. Rev., 219: 36-46.

WALLINGA J., CUNNINGHAM A.C. 2015 - Luminescence Dating, Uncertainties, and Age Range. [W:] Rink W.J., Thompson J.W. Encyclopedia of Scientific Dating Methods. Springer Reference: $440-445$.

WECKWERTH P., PRZEGIETKA K. CHRUŚCIŃSKA A., WORONKO B., OCZKOWSKI H.L. 2011 - Age and sedimentological features of fluvial series in the Torun basin and the Drwęca valley (Poland). Geochronometria, 38: 397-412.

WOŹNIAK P.P. 2004 - Przydatność analizy litologicznej glin morenowych w badaniach geomorfologicznych stref marginalnych ostatniego zlodowacenia. Prz. Geol., 52 (4): 336-339.

WÜTHRICH L., BRÄNDLI C., BRAUCHER R., VEIT H., HAGHIPOUR N., TERRIZZANO C., CHRISTL M., GNÄGI C., ZECH R. 2017

$-{ }^{10} \mathrm{Be}$ depth profiles in glacial sediments on the Swiss Plateau: deposition age, denudation and (pseudo-)inheritance. E\&G Quatern. Sci. J., 66: $57-68$.

WYSOTA W., MOLEWSKI P., SOKOŁOWSKI R.J. 2009 - Record of the Vistula ice lobe advances in the Late Weichselian glacial sequence in north-central Poland. Quat. Intern., 207: 26-41.

ZABIELSKI R. 2004 - Jakie cechy składu petrograficznego żwirów glin lodowcowych mogą być przydatne w litostratygrafii? Prz. Geol., 52 (4): 340-346.

ZARETSKAYA N., PANIN A., MOLOD'KOV A., TROFIMOVA S., SIMAKOVA A., BARANOV D. 2020 - Pleistocene stratigraphy of the Vychegda River basin, European North-East. Quat. Intern., 546: 185-195.

Praca wpłynęła do redakcji $4.05 .2020 \mathrm{r}$.

Akceptowano do druku 10.09.2020 r. 